\title{
Teaching Philosophy Embedded in The Sound of Music*
}

\author{
ZHANG Yan-hua \\ Weifang Medical University, Weifang, China
}

\begin{abstract}
Maria is the heroine in the movie The Sound of Music. She leaves an Austrian convent to be a governess at Captain Georg von Trapp’s home. With her kindness, honesty, and teaching wisdom, she wins the seven children’s trust, respect, and love. This paper analyzes the teaching philosophy embedded in this film, such as how to identify students' strengths and weaknesses to develop their potentials, how to encourage students to meet new challenges, how to improve students' ability to resist frustration, how to understand students and build a harmonious relationship with them, and how to teach students with effective methods, etc., teachers can benefit a lot from this aesthetically significant film from the perspective of pedagogy and psychology.
\end{abstract}

Keywords: The Sound of Music, Maria, teaching philosophy, inspiration

\section{Introduction}

The Sound of Music directed and produced by Robert Wise and starring Julie Andrews and Christopher Plummer in 1965 is one of the favorite musical movies in the world. The film is derived from the Broadway musical play with the same title The Sound of Music. Based on the book The Story of the Trapp Family Singers published in 1945, the film is about a young woman named Maria, who leaves an Austrian convent to become a favorite governess to the seven children of a naval officer widower, Captain Georg von Trapp, and at last, they fall in love with each other and get married. The film won five Academy Awards including "Best Picture" and "Best Director". It displaced the popular film Gone with the Wind as the highest-grossing one of all-time.

At the end of the 1980s, the author had a chance to enjoy The Sound of Music for the first time. As a result, it impressed and moved her deeply with its humane characters, melodic and tuneful music as well as its stunningly beautiful scenery. It is really an aural as well as a visual delight. What is more, the successful governess, Maria, whose teaching philosophy, special innovation in teaching gives her inspirations about how to be a good teacher. This is the reason why the author recommends the students (who major in English) having the opportunity to be English teachers to see the movie for many years. It is a coincidence that recently the author read a report saying, in a teacher development program in China, The Sound of Music was applied as one of the training contents in teachers' ethic devotion. In 2001, the United States Library of Congress selected the film for preservation in the National Film Registry as it was deemed "culturally, historically, or aesthetically significant”. A film exerts such a profound influence on people from different countries at different times. This paper focuses on the inspirations

\footnotetext{
* Acknowledgements: This paper is part of the author's academic studies project sponsored by Social Science Planning Fund Program, Shangdong Province (13CWJZ18) \& Medical Education Branch of Chinese Medical Association Program (2012-YY-17).

ZHANG Yan-hua, associate professor, master, English Department, Weifang Medical University.
} 
teachers can draw from the film and apply them for reference in practical teaching.

\section{To Find the Potentials of Students}

In the film, Maria is fond of music, nature, and life. She cannot help dancing and singing in the fields, "For a thousand years, the hills fill my heart. With the sound of music, my heart wants to sing every song it hears.” In her eyes, there is happiness everywhere. She often loses herself in music, wandering in her happiness. In the beauty of the wild nature, she finds the most comfortable shelter for her soul in. While as a nun in an abbey, she is not approved by the other sisters. They think, "She (Maria) is not an asset to the abbey."

Individuals differ in the strength of intelligences. In 1993, Gardner developed the theory of multiple intelligences in Multiple Intelligences, which has emerged from cognitive research. Gardner made the following categories: (1) Linguistic intelligence, (2) Logical-mathematical intelligence, (3) Body kinesthetic, (4) Spatial intelligence, (5) Musical intelligence, (6) Intrapersonal intelligence, (7) Interpersonal intelligence, and (8) Naturalist intelligence. Gardner (1993) believes that every person has a relatively independent of the eight kinds of intelligence, but each has its own unique understanding of intellectual development process and system of signs.

Maria is active and energetic, full of the power of character, she is not suitable for strict disciplines in the abbey. The reverend mother in the abbey uses some metaphors to describe her personality, "how do you catch a cloud and pin it down? How do you keep a wave upon the sand? How do you hold a moonbeam in your hand?” Maria is articulate with a variety of interests, in the mother's perspective, she is an ideal candidate to be a governess with her own strong points. The reverend mother is wise enough in recognizing Maria's potentials to assign her to be the children's governess. It is Maria's power of character and her positive attitude to life that contribute to her new career-a governess of the seven children. Maria becomes a successful teacher, not beyond the reverend mother's expectation. As Multiple Intelligences reveals, teachers should understand that every student is unique with their own potentials, trying to analyze and understand their strengths and weaknesses. In this way, teachers can develop students' recognition, affection, and ability respectively with appropriate methods and give them advice or guide in career planning in the future.

\section{To Encourage Yourself to Meet New Challenges}

Do you still remember the time when you stand on the teaching platform as a teacher? Maybe at the very beginning, you had a haze of fear, nervousness, and confusion. Maria also shows her upset when she was assigned to be the governess of the Captain's seven children. She does not know what her future will be. Can she be accepted by the children? "Why am I so scared?” She tries to maintain her optimism, "I must stop these doubts all these worries. I'm seeking the courage I lack, the courage to serve them with reliance." She encourages herself to "face my mistakes without defiance, show them I'm worthy". In fact, she does psyche herself up to meet the challenge to be a governess of seven children: "I have confidence they'll put me to the test. I will impress them I will be firm but kind."

Maria uses the positive words above to enhance her self-confidence. If you are nervous or upset when meeting any challenges, remember to learn from Maria: Encourage yourself with such positive words. Rakesh K. Mittal ever said, with a positive mindset every problem is a new challenge and an opportunity. The power of 
positive words will help you to attain courage and happiness as it is full of practical wisdom drawn from ordinary daily episodes. It will inspire you to develop a positive outlook towards life and society. These positive words would give you some unexpected benefits, gradually you will be more confident, and you will have a more positive attitude to life.

\section{To Understand the Naughty Students}

There were ever 12 governesses before Maria came to Captain Georg von Trapp’s home. They came and left, no one ever stayed here long because the children are pretty naughty. Maria also psyches herself up for the children's naughty behavior,

Let them bring on all their problems, I'll do better than my best. Everything will turn out fine, I have confidence the world will all be mine, they'll have to agree I have confidence in me, I have confidence the world can all be mine.

The seven children of Captain Georg von Trapp are defensive to Maria when she comes to be a new governess. Just read their dialogues when they first meet each other:

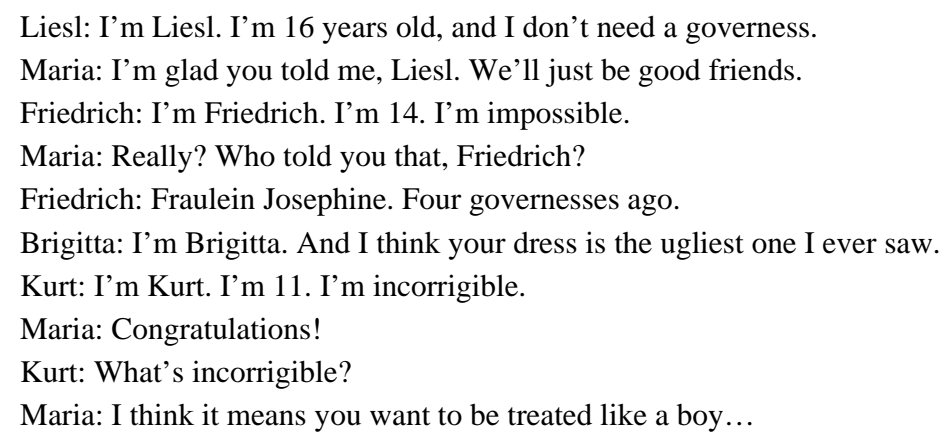

The children's innocence and naughtiness as well as Maria's wisdom in education can be revealed preliminarily in their dialogues. Facing Lisa and Gita's direct challenge, she is not embarrassed or irritated, just saying "I'm glad you told me, we can be friends". Kurt's "incorrigible" is also interpreted as "you want to be treated like a boy", a very positive signification with a teacher's good intention. These words have positive implications and expectation in children's growth and development, which is also beneficial to promote their student-teacher relationship.

After they meet each other, the seven children use various kinds of tricks to make fun with her: putting a toad in her pocket secretly when she goes upstairs, making her so scared; putting a pine cone in her chair before dinner, when she sits down, she cannot help giving a painful scream. She is so embarrassed in front of all the family members including the captain.

Maria knows it is children's nature to be fond of playing tricks. What is more, the children lost their mother when they were young and their father is so strict with them that they seldom have a chance to express their inner feelings. The former governesses were often caustic and mocking at them. Facing with the children's practical jokes, Maria shows her understanding, patience, and great tolerance. She tells nothing to their father, the captain. At the dinner table, she just says humorously, "I'd like to thank you all for the precious gift you left in my pocket today.” When the captain asks what gift it is, she just says, "It's a secret between the children and me.” She also says frankly, 
Knowing how nervous I must have been, a stranger in a new household... Knowing how important it was for me to feel accepted. It was so kind and thoughtful of you to make my first moments here so warm and happy and pleasant...

Here Maria shows her great wisdom in dealing with children. It is her kindness and wisdom that help her to resolve the children's prank and her embarrassing situation. The children perceive Maria's kindness and sincerity; they are so moved and touched. Maria's positive personality helps her win the trust, respect, and love of the children. Soon they set up a harmonious teacher-student relationship, which is essential in effective teaching. There is an old saying, “pupils don’t learn anything from people they don’t like.” Both teachers and students can benefit a lot from a harmonious relationship between them.

\section{To Respect Students Who Have Puppy Love}

The eldest daughter Liesl, 16-year-old, fell in love with the young postman named Rolfe. One day, they open their hearts and speak lovers' prattle until midnight regardless of the rain. Liesl ignores the time to go home. As a result, she cannot get into the house because it is locked. Fearing that her father will punish her, she just climbs the walls to enter it. Maria does not blame her, nor does she let others know. Instead, she invites her to her room to have a talk and gives her dry clothes to change so that she will not be noticed by others. Liesl is so moved that she changes her attitude to Maria, “I ever told you I didn’t need a governess, but, maybe, I do.”

Maria and Liesl become good friends and get along well with each other and fit in beautifully. After Liesl is disappointed in love, she comforts her and tries to enlighten her. Under the influence of Maria, Liesl becomes a little assistant, she opens her heart, sharing her secrets and confusion in her mind to Maria. The other children are not lonely any longer; they also share their feelings with Maria without any restraints. They have increasing love to Maria and their family.

Many students in China have experienced puppy love, which interfere with their learning because some of them cannot balance their love and learning. Teachers should respect and understand their affection, because it is inevitable to produce such feelings to the opposite sex at their age. Teachers can advise them to read some famous people's biographies to help them find role models in their growth and learn to treat their emotion and learning wisely. Teachers' understanding and solicitude are helpful to establish a good relationship with students. They are more willing to open their inner world and communicate better with teachers, who can provide students immediate help once there are any problems. In this way, students can benefit a lot from teachers' guidance and advice to treat puppy love more wisely.

\section{To Improve Students' Ability to Resist Frustration in Life}

Maria's parents died when she was only two years old, but she did not wallow in self-pity. Instead, she is optimistic with a bright and cheerful personality, showing great passion to nature and music. Twists and turns are a part of life and setbacks often happen. Life is full of ups and downs. When students meet with setbacks and frustrations, how to motivate and comfort them? Maria also sets a good role model.

At a lightening night with rumbling of thunder and flashes, the children are so scared, and they all run to Maria’s room. Maria encourages them, “You’re not frightened of a storm.” When the children asked, “Why does it do that?” Maria answers them in a very humorous and vivid way, "The lightning talks to the thunder, and the thunder answers.” Lightning and thunder are compared to a talk between them, what a miraculous analogy! 
Whenever I'm feeling unhappy, I just try to think of nice things. Daffodils, green meadows, skies full of stars, raindrops on roses and whiskers on kettens, bright copper kettles and warm woolen mittens... wild geese that fly with the moon on their wings... silver white winters that melt into springs, these are a few of my favorite things.

“When the dog barks, when the bees bite, I simply remember my favorite things and then I don’t feel so bad." The children dance and sing together with Maria, not frightening of the thunderstorm any longer. They know the fact that the unpleasant things are inevitable to meet with in life. At that time, they just think of their favorites, the unpleasant feelings such as anxiety or fear will disappear.

In China, Meng Zi (a thinker and educator in Warring States Period, about in 372-289 BC) ever said,

When Heaven is about to place a great responsibility on a great man, it always first frustrates his spirit and will, exhausts his muscles and bones, exposes him to starvation and poverty, harasses him by troubles and setbacks so as to stimulate his spirit, toughen his nature and enhance his abilities.

Setbacks and frustrations are indispensible in life. If teachers help students to realize the significant role that setbacks or difficulties play in the process of their grown and development, they will be more optimistic and more prepared when they meet with difficulties or troubles.

\section{To Teach Students Effectively}

At the very beginning of the film, when the audiences follow Maria to Captain Georg von Trapp’s home, what they find is a family with strict discipline. The captain uses a whistle to summon his children. He also issues orders to his children like to his soldiers, and dresses them in sailor-suit uniforms. Under the rigid rules, the nature of the children is limited, they have no songs, no laughers, and they are only fond of playing tricks on people. Maria discovers it is not suitable to children at all.

Maria respects children's interests and hobbies. Although initially hostile toward her, the children become friendly to her. Quickly, she obtains the trust of the children. She teaches effectively the children in accordance with their nature and different personality.

The first lesson is carried out in the beautiful nature, Maria teaches them through lively activities. Education cannot thrive without enjoyment. Maria teaches the children to sing, "When you read, you begin with A-B-C; when you sing, you begin with Do-Re-Me.” Do-Re-Me is the musical notes one must learn to sing songs. In order to help them to understand and memorize the notes, she compares the abstract musical notes and the familiar lovely things with the method of harmonic tone:

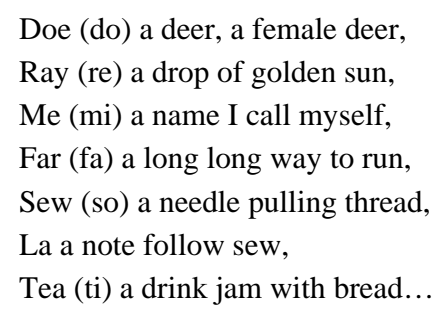

Maria combines education with pleasure with the heuristic education, arousing children's curiosity and interests, making difficult things simple and changing the abstract to the concrete. Gradually, the children have the same infectious enthusiasm to join the song. They are learning and singing happily, spreading the happiness 
and singing amongst all the way in the field, and in the valley. Music draws the distance closer between Maria and the students, the children become increasing cute and sensible, and their hospitality to Maria disappears completely.

\section{Conclusion}

An old proverb ever says, it is love that makes the world go round. Maria uses her kindness, honesty, tolerance, and wisdom to teach the children effectively, resolving children's pranks and solving the embarrassment humorously, which reflects her ethic devotion, professional qualities, and personal styles in education. Consequently, Maria wins the children's trust, respect, and love. In addition, Maria also sets a role model in the perspective of pedagogy and psychology, enlightening teachers to understand students and create a harmonious relationship with them, to arouse their curiosity and interest to knowledge, to encourage them to meet new challenges, to improve their competences respectively and teach more effectively.

\section{References}

Arnold, J. (1999). Affect in language learning. London: Cambridge University Press.

Gardner, H. (1993). Multiple intelligences: New horizons in theory and practice. New York: Basic Books.

Harmer, J. (2010). How to teach English. Beijing: Foreign Language Teaching and Research Press.

Klages, M. (2006). Literary theory: A guide for the perplexed. Shanghai: Shanghai Foreign Language Education Press.

SUN, Y. Z. (2008). English education and liberal education. Beijing: Foreign Language Teaching And Research Press.

Wise, R. (Director \& Producer). (1965). The sound of music [Film]. Los Angeles: 20th Century Fox.

ZHANG, J. (2008). Selected readings in British and American poetry. Beijing: Foreign Language Teaching And Research Press.

ZHANG, Y. H., \& LI, C. L. (2009). Inspirations educators can get from Maria in The Sound of Music. Film Review, (07), $49,59$. 